\title{
Phytochemical Nature and Pharmacological Evaluation of Chloroform Extract of Pandanus fascicularis L. (Fruits): An in vivo Study
}

Sadhan Baul ${ }^{1}$, Mohammad Nurul Amin ${ }^{1,3}$, Md Saddam Hussain ${ }^{1,3}$, Md Emdadul Hasan Mukul ${ }^{2}$, Md Shalahuddin Millat ${ }^{1,3}$, Md Saif Uddin Rashed $^{4}$, Sharmeen Asad ${ }^{5}$, Rajib Chandra Das ${ }^{6}$, Md Saiful Islam Arman ${ }^{6}$, Md Tanvir Haider Tanna ${ }^{1}$ and Latifa Bulbul ${ }^{*}$

${ }^{1}$ Department of Pharmacy, Noakhali Science and Technology University, Bangladesh

${ }^{2}$ Department of Pharmacy, Khwaja Yunus Ali University, Sirajganj, Bangladesh

${ }^{3}$ Department of Pharmacy, Atish Dipankar University of Science and Technology, Banani, Dhaka, Bangladesh

${ }^{4}$ Department of Finance and Banking, University of Barisal, Barisal, Bangladesh

${ }^{5}$ Department of Pharmacy, State University of Bangladesh, Dhaka, Bangladesh

${ }^{6}$ Department of Applied Chemistry and Chemical Engineering, Noakhali Science and Technology University, Bangladesh

\begin{abstract}
The current study was undertaken to investigate analgesic, anti-pyretic, anti-inflammatory, and gastrointestinal (GI) motility of fruit extract of $P$. fascicularis $\mathrm{L}$. The analgesic potentials of plant extract was screened by using the acetic acid-induced writhing test. Antipyretic study was done by yeast induced pyrexia. The extracts were used for anti-inflammatory studies by albumin induced edema over a period of time; finally, gastrointestinal (GI) motility test was performed using charcoal. The chloroform extracts showed presence of maximum phytochemicals such as alkaloid, tannin, saponin, steroid, terpenoid, protein, flavonoid etc. In case of analgesic assay the dose of $400 \mathrm{mg} / \mathrm{kg}$ was capable of inhibiting $62.96 \%$ writhing in comparison to standard Diclofenac sodium, while our antipyretic assay were resembled initial $\left(38.7 \pm 0.45^{\circ} \mathrm{C}\right)$ and final $\left(37.83 \pm 0.37^{\circ} \mathrm{C}\right)$ rectal temperatures when treated with chloroform extract $(400 \mathrm{mg} / \mathrm{kg})$; where the values for Acetyl salicylic acid $(100 \mathrm{mg} / \mathrm{kg})$ were found $38.4 \pm 0.11^{\circ} \mathrm{C}$ and $37.5 \pm$ $0.010^{\circ} \mathrm{C}$ respectively. During anti-inflammatory assay edema was reduced from $0.62 \pm 0.06$ to $0.45 \pm 0.02$ after $5 \mathrm{~h}$ of administration of chloroform extract $(400 \mathrm{mg} / \mathrm{kg}$ ), where aspirin did this from $0.60 \pm 0.002$ to $0.42 \pm 0.01 \mathrm{at} 200 \mathrm{mg} /$ $\mathrm{kg}$ dose. The motility rates of castor oil and chloroform extract were found $53.24 \%$ and $31.78 \%$ at $10 \mathrm{ml} / \mathrm{kg}$ and 400 $\mathrm{mg} / \mathrm{kg}$ respectively, where the control represented $63.68 \%$ motility rate. These results show that, chloroform extract of fruit of $P$. fascicularis L. has significant analgesic, anti-pyretic, anti-inflammatory and gastrointestinal (GI) motility effects that increase with the increase of concentration. It can be assumed that, phytochemicals present, are the source of potency of the chloroform extract.
\end{abstract}

Keywords: P. fascicularis L; Pyrexia; Oedema; Gastrointestinal (GI) motility; LC50

\section{Introduction}

Medicinal plants have always been considered a healthy source of life for all people. These plants are very useful in healing various diseases because of their therapeutic properties and the advantage of these medicinal plants is being $100 \%$ natural. Since historical instances, natural preparations had been used for the treatment of several diseases. Herbal products are frequently perceived as secure because they're "herbal" $[1,2]$. World Health Organization (WHO) directed medicinal vegetation as a handy, affordable and culturally suitable source of number one health take care of greater than $80 \%$ of global population [1,2]. Botanical medicine or phytomedicine refers to the use of any plant's seeds, berries, roots, leaves, bark, or flowers for medicinal purposes [3]. Even among prescription drugs, minimum $25 \%$ contain at least one compound derived from plants. The percentage might be higher if we include overthe-counter (OTC) drugs [4]. In developing countries, about $75 \%$ of the world populations rely on traditional medicine for their primary health care [5]. Herbal medicines are gaining interest because of their cost effectiveness and eco-friendly attributes [6].

P. fascicularis L. is a coastal plant which belongs to the family of Pandanaceae (screw pine family). In Bangladesh it's far referred to as Keora, Keya and Ketaki. Although Pandanus bushes grow almost everywhere in tropical Asia, kewra water continues to be specifically a Northern Indian flavoring that is not used anywhere else. Indian emigrants, but, have taken their likening for this flavor with them, and have transported pandanus timber to different tropical areas [7]. In Western cooking, Kewra water makes a quality opportunity to the flower essences already in use, like rose or orange. The ripe culmination of $P$. fascicularis has challenge with their fragrance to crucial oil ruled with the aid of esters. Besides geranyl acetate, more than one hemiterpenoid esters had been found: isopentenyl (3-methylbut-three-enyl) and, to a lesser degree, dimethyl allyl (3-methylbut-2-enyl) acetates and cinnamates [7].

Pain is an unsightly sensory and emotional experience associated with real or absolute tissue damage [8]. By appearing inside the central nervous system (CNS) or on the peripheral pain mechanism, analgesic compounds selectively relieves ache without extensive alteration of cognizance. Actually analgesics are implemented while the noxious stimulus cannot be eliminated or as adjuvant to greater etiological approach to ache [9]. Pyrexia or fever is described as an elevation of frame temperature. It is a reaction because of tissue damage, inflammation, malignancy or graft rejection. Cytokines, interleukin, interferon and tumor necrosis factor $\alpha(\mathrm{TNF}-\alpha)$, all are fashioned in big amount under this situation, which risen prostaglandin E2 (PGE2) level, which in turn triggers hypothalamus to raise body temperature

*Corresponding author: Latifa Bulbul Assistant Professor, Department of Pharmacy, Noakhali Science \& Technology University, Sonapur-3814, Noakhali, Bangladesh. Email: latifa.nstu@gmail.com

Received August 09, 2017; Accepted August 20, 2017; Published August 29 2017

Citation: Baul S, Amin MN, Hussain MS, MEH Mukul, Millat MS, et al. (2017) Phytochemical Nature and Pharmacological Evaluation of Chloroform Extract of Pandanus fascicularis L. (Fruits): An in vivo Study. J Bioanal Biomed 9: 223-228. doi:10.4172/1948-593X.1000183

Copyright: ( $) 2017$ Baul S, et al. This is an open-access article distributed under the terms of the Creative Commons Attribution License, which permits unrestricted use, distribution, and reproduction in any medium, provided the original author and source are credited. 
[10]. Fever is associated with symptoms of sickness conduct which include lethargy, despair, anorexia, sleepiness, and incapacity to pay attention. Also triggers expanded muscle tone and shivering. However antipyretic medicinal drug can be powerful at lowering the temperature which may consist of the affected person's comfort [11]. Regulation of body temperature requires a sensitive stability among production and loss of heat, and the hypothalamus which modify the set factor of body temperature. Drugs like paracetamol do now not have an impact on frame temperature whilst multiplied through factors which include exercising or boom in ambient temperature [12]. One of the maximum vital pathological sicknesses is inflammation. It is a part of non-particular immune reaction that takes place in response to any kind of bodily injury, is a complicated biological response of vascular tissues to harmful stimuli [13]. It entails a complex array of enzyme activation, mediator release, and extravasations of fluid, cell migration, tissue breakdown and repair. Non-steroidal anti-inflammatory drugs (NSAID) are many of the most generally prescription drugs because of their consistent effectiveness within the remedy of pain, fever, inflammation and rheumatic disorders. However, their use are associated with unfavourable effects at the extent of digestive tract, starting from dyspeptic symptoms, gastrointestinal erosions and peptic ulcers to extra serious complications, which include over bleeding or perforation [14]. Development of recent anti-inflammatory tablets remains necessary and the natural product such as medicinal flowers could lead in discovering new anti-inflammatory drugs with less undesirable effects [15-17]. Diarrhoea l sicknesses are one of the leading causes of morbidity and mortality in developing nations and are liable for the death of millions of human beings every year. It may be defined as the expanded frequency of bowel moves followed via an unfastened consistency of stools [18]. Modern estimate suggests that approximately 2.5 billion cases of diarrhoea arise every year which leads to 1.5 million deaths among children below the age 5. Diarrhoea nonetheless stays the second leading motive of toddler mortality [18]. The situations of diarrhoea are especially risky in infants and younger youngsters because of the rapidity with which severe dehydration arise. Secretory diarrhoea is the not unusual shape of acute diarrhoea which takes place due to improved intestinal secretion or reduced intestinal absorption of fluid and electrolytes or via altered motility of gastro-intestinal tract [18]. The present study was undertaken to evaluate possible in vivo analgesic, anti-pyretic, anti-inflammatory, and gastro-intestinal motility activities of chloroform extract of $P$. fascicularis L. (fruits).

\section{Materials and Methods}

\section{Chemicals and reference drugs}

Chemicals and other additives used in this study purchased from Sigma-Aldrich Co. (St. Louis, MO, USA), and Merck (Darmstadt, Germany), and were of analytical grade.

\section{Collection of plant materials}

Plant materials were collected from coastal region of Noakhali.

\section{Plant extracts preparation and isolation}

After collection fruits of $P$. fascicularis L. were appropriately cleaned with water. Mechanical graded aluminum foil was used to air-dry the fruits and finally kept at room temperature for 14 days [18]. Then the accrued plant substances have been chopped and powdered. About $500 \mathrm{~g}$ of the powdered substances of the plant were soaked in $1.5 \mathrm{l}$ of chloroform at room temperature for 2 weeks. The sample mixture were shacked and stirred at regular interval during this time. Then the solution become filtered by the use of filter cloth and Whatman's filter out paper and concentrated with a rotary evaporator. It turned into brown granular which was then designated as crude chloroform extracts for further study.

\section{Test animals}

For the evaluation of in vivo analgesic, anti-pyretic, gastro-intestinal motility and anti-inflammatory activities of chloroform extract of $P$. fascicularis L. (fruits), young Swiss-albino mice (aged 20-25 days) of either sex, average weight 20-25 g were used. They were accumulated from the Animal Resources Branch of ICDDRB (International Centre for Diarrhoea Disease and Research, Bangladesh). After collection, they have been kept in favorable situation (temperature: $25.0 \pm 1.0^{\circ} \mathrm{C}$, relative humidity: $55-65 \%$ and $12 \mathrm{~h}$ mild/darkish cycle) for one week. The tests become done according to the protocol authorised by the Animal Ethics Committee of NSTU Research Cell, Noakhali Science and Technology University, and the internationally recognized principles were accompanied for laboratory animal use and care.

\section{Phytochemical screening}

Small quantity of freshly prepared chloroform extracts of $P$. fascicularis L. (fruits) were subjected to investigate quantitative preliminary phytochemicals such as alkaloids, carbohydrates, glycosides, phytosterols, proteins, flavonoids, tannins, saponins, phenols, gums and mucilages, fats and fixed oils by following the standard methods given by Roopashree et al. [19].

\section{Analgesic activity}

The crude chloroform extract of $P$. fascicularis L. (culmination) was used to assess analgesic potential by way of using the version of acetic acid caused writhing in mice [9]. Experimental animals had been randomly decided on and divided into four businesses denoted as organization I, institution II, organization III, and group IV. Each mouse changed into weighed nicely and the doses of the take a look at samples and control substances have been adjusted consequently. Each group changed into designed to obtain the following treatment consisting of; controls, wonderful manipulate (preferred Diclofenac $\mathrm{Na}$ ) and two doses $(200 \mathrm{mg} / \mathrm{kg}$ and $400 \mathrm{mg} / \mathrm{kg}$ body weight $)$ of the extract answer respectively. Positive control institution turned into treated with the dose of $25 \mathrm{mg} / \mathrm{kg}$-body weight and control group has been administered with $1 \%$ Tween 80 in water on the dose of 15 $\mathrm{ml} / \mathrm{kg}$-frame weight. Control, general drug and tested samples were administered orally $30 \mathrm{~min}$ earlier than intraperitoneal administration of $0.7 \%$ acetic acid.

\section{Anti-pyretic activity}

The antipyretic activity was evaluated with the aid of Brewer's yeast prompted pyrexia in experimental animal [1]. Hyperpyrexia was triggered via subcutaneous management of $20 \%$ aqueous suspension of brewer's yeast at the dose of $10 \mathrm{ml} / \mathrm{kg}$ body weight. The check animals were fasted in a single day with water ad libitum before the experiments. By using an Ellab thermometer $\left(33.19^{\circ} \mathrm{C} \pm 0.40^{\circ} \mathrm{C}\right)$ the initial rectal temperature of check animals had been recorded. After 18 $\mathrm{h}$ of subcutaneous injection, the animals that showed an increase of $0.3^{\circ} \mathrm{C}-0.5^{\circ} \mathrm{C}$ in rectal temperature have been selected for the antipyretic activity. Crude chloroform extracts of plant had been given orally at the dose of $200 \mathrm{mg} / \mathrm{kg}$ and $400 \mathrm{mg} / \mathrm{kg}$ respectively. Paracetamol (150 $\mathrm{mg} / \mathrm{kg}$ orally) used as reference drug while; distilled water $(10 \mathrm{ml} / \mathrm{kg})$ become treated as control group. The rectal temperature was recorded for 4 times at $1 \mathrm{~h}$ periods after treatment. 


\section{Anti-inflammatory activity}

The rat paw edema technique of Winter et al. [20,21] become used. Garden egg extract (one hundred, two hundred and four hundred $\mathrm{mg} / \mathrm{kg}$, I.P.) or indomethacin (10 $\mathrm{mg} / \mathrm{kg}$, I.P.) suspended in ordinary saline had been administered to the rats $(1 \mathrm{~mL} / \mathrm{kg}$, I.p.). $1 \mathrm{~h}$ post treatment, inflammation was induced in the hind paw by injecting 0.1 $\mathrm{mL}$ of undiluted clean egg albumin into the sub plantar surface of the proper hind paw of rats. The right hind paw volumes of the rats were taken on the principle of volume displacement using LETICA Digital Plethysmometer (LE 7500) immediately before the experiment (zero time) and at $1 \mathrm{~h}$ intervals after the injection of egg albumin for a period of $5 \mathrm{~h}$. The common edema at every interval become assessed in terms of difference in extent displacement after injecting the egg albumin and 0 time volume displacement of the injected paw (Vt-V0). Percent inhibition of edema became additionally calculated for each treated group.

\section{Gastrointestinal motility test}

This test was carried out by the approach of Rahman et al. [22]. For this test, experimental rats were divided into 4 agencies of five rats in every. At first, $1 \mathrm{~mL}$ castor oil turned into given orally in every rat of every organization to supply diarrhoea. After $1 \mathrm{~h}$, Group I (control) obtained saline $(2 \mathrm{~mL} / \mathrm{kg})$ orally. Group II obtained widespread drug (Loperamide five $\mathrm{mg} / \mathrm{kg}$ b. Wt. I.P) and Groups III-IV obtained MEMA (200 and $400 \mathrm{mg} / \mathrm{kg}$ b. Wt. I.P.). After $1 \mathrm{~h}$, all animals obtained $1 \mathrm{~mL}$ of charcoal meal (10\% charcoal suspension in $5 \%$ gum acacia) orally. $1 \mathrm{~h}$ after following the charcoal meal management, all animals have been sacrificed and the gap covered by means of the charcoal meal inside the gut, from the pylorus to the caecum, was measured and expressed as percent of distance moved.

\section{Statistical analysis}

All the above assays were carried out in triplicate and repeated threes for consistency of consequences and statistical causes. The statistics had been expressed as Mean \pm SD and analyzed by using the SPSS software of 10 versions.

\section{Results}

\section{Phytochemical nature}

Phytochemical analysis of chloroform extract of fruits of $P$. fascicularis revealed the presence of alkaloids, steroids, terpenoids, flavonoids, saponis, proteins and tannins (Table 1).

\section{Acute toxicity study}

The chloroform extract fruits of $P$. fascicularis administered to a

\begin{tabular}{|l|c|}
\hline Bioactive constituents & Chloroform extract \\
\hline Alkaloids & + \\
\hline Steroids & + \\
\hline Terpenoids & - \\
\hline Phenols & - \\
\hline Glycosides & - \\
\hline Carbohydrates & + \\
\hline Proteins & + \\
\hline Flavanoids & + \\
\hline Saponins & + \\
\hline Tannins & \\
\hline Here, "+"=Present, and "-"= Absent & + \\
\hline
\end{tabular}

Table 1: Result of phytochemical screening of different fractions of fruits of $P$ fascicularis. dose of $4000 \mathrm{mg} / \mathrm{kg}$ and produced no mortality of the experimental animals. Thus the LD50 value was found to be greater than $4000 \mathrm{mg} / \mathrm{kg}$ body weight. The animals did not manifest any sign of fever, diarrhoea, dysentery, bleeding per rectum, mal-absorption syndrome.

\section{Analgesic activity}

The number of writings of all test animals and mean cumulative total of writings in the intervention groups are presented in Table 2. From Table 2 it has been seen that there was a reduction in the cumulative total of writings in the chloroform extract groups and the Diclofenac sodium group, in comparison with the negative controls receiving $1 \%$ tween 80. This indicates that Diclofenac and P. fascicularis chloroform extract at the two dosages were capable of reducing writhing in mice. The dose of $400 \mathrm{mg} / \mathrm{kg}$ is significantly capable of inhibition (\%) of writhes at $62.96 \%$ comparison with standard Diclofenac sodium (150 $\mathrm{mg} / \mathrm{kg} \mathrm{b.w)}$ at $67.74 \%$. That means chloroform extract of $P$. fascicularis (fruit) at $400 \mathrm{mg} / \mathrm{kg}$ dose shows significant analgesic activity.

\section{Antipyretic activity}

Chloroform extract produced significant antipyretic activity $(p<0.05)$. Chloroform extract produced noticeable antipyretic effect $(p$ zero.05). Traditionally, non-steroidal anti-inflammatory pills produce their antipyretic motion via the inhibition of prostaglandin synthetase in the hypothalamus. Therefore, the antipyretic activity of chloroform extract of $P$. fascicularis is probably with the aid of inhibition of prostaglandin synthesis in hypothalamus. Further, chloroform extract was determined to contain alkaloids, steroids, terpenoids, flavonoids, and tannins through initial photochemical screening. The antipyretic activity can be due to one/multiple organization of above phytomaterials. Extract reduced the hyperthermia at each 200 and $400 \mathrm{mg} /$ $\mathrm{kg}$ doses at $1 \mathrm{~h}$ after management. The primary and terminal rectal temperatures in the groups treated with chloroform extract $(400 \mathrm{mg} /$ $\mathrm{kg})$ and Acetyl salicylic acid $(100 \mathrm{mg} / \mathrm{kg})$ were found $38.7 \pm 0.45$ and $37.83 \pm 0.37$; and $38.4 \pm 0.11$ and $37.5 \pm 0.01^{\circ} \mathrm{C}$ respectively which are represented in Figure 1.

\section{Anti-inflammatory activity}

Chloroform extract produced significant anti-inflammatory activity $(\mathrm{p}<0.05)$. In general, non-steroidal anti-inflammatory drugs produce their anti-inflammatory movement through the inhibition of prostaglandin synthetase within the hypothalamus. Therefore, the antiinflammatory interest of chloroform extract of $P$. fascicularis might be by way of inhibition of prostaglandin synthesis in hypothalamus.

Further, chloroform extract was found to contain alkaloids, terpenoids, proteins, flavonoids and tannins through preliminary photochemical screening. The anti-inflammatory activity can be due to one/more group of above Phytoconstituents. Extract decreased the paw edema at each 200 and $400 \mathrm{mg} / \mathrm{kg}$ doses at $1 \mathrm{~h}$ after administration. The initial and very last edema is $0.62 \pm 0.06$ and $0.45 \pm 0.02$ for chloroform extract $(400 \mathrm{mg} / \mathrm{kg})$ and $0.60 \pm .002$ and $0.42 \pm 0$ for aspirin $(100 \mathrm{mg} /$

\begin{tabular}{|l|c|c|c|}
\hline Sample/Drugs & $\begin{array}{c}\text { Dose (mg/ } \\
\mathbf{k g})\end{array}$ & $\begin{array}{c}\text { Writhing count (Mean } \pm \\
\text { S.E.M.) (15 min) }\end{array}$ & \% of Inhibition \\
\hline Control & $10 \mathrm{ml} / \mathrm{kg}$ & $54 \pm 4.848$ & 0 \\
\hline Diclofenac sodium & $150 \mathrm{mg} / \mathrm{kg}$ & $17.6 \pm 3.701$ & 67.74 \\
\hline Chloroform extract & $200 \mathrm{mg} / \mathrm{kg}$ & $33 \pm 2$ & 37.03 \\
\hline Chloroform extract & $400 \mathrm{mg} / \mathrm{kg}$ & $18.66 \pm 4.04$ & 62.96 \\
\hline \multicolumn{4}{|l|}{ Values are represented as mean \pm SD } \\
\hline
\end{tabular}

Table 2: Effect of chloroform extract of $P$. fascicularis (fruit) on acetic acid induced writhing in mice. 
$\mathrm{kg}$ ) remedy. Both aspirin and chloroform extract showed enormous anti-inflammatory interest throughout the duration of five hour, which have been showed in Figure 2.

\section{GI motility}

The activity of GI motility of chloroform extract of $P$. fascicularis is tabulated in Table 3 . The results were articulated as mean \pm SEM of six animals. Effects were found to be significant at the $\mathrm{P}<0.05$ level. From the Table 3, it is seen that chloroform extract exert GI motility activity. The both dose $200 \mathrm{mg} / \mathrm{kg}$ and $400 \mathrm{mg} / \mathrm{kg}$ decrease motility (\%) rate of mice comparison with castor oil. The Total length of intestine and distance covered by charcoal are $50.25 \pm 7.27$ and $23.5 \pm 3.31$ for castor oil at a dose of $10 \mathrm{ml} / \mathrm{kg}$ and $53.5 \pm 9.03$ and $36.5 \pm 6.02$ for

\begin{tabular}{|l|c|c|c|c|}
\hline Treatment & Dose & $\begin{array}{c}\text { Total length } \\
\text { of intestine }\end{array}$ & $\begin{array}{c}\text { Distance } \\
\text { covered by } \\
\text { charcoal }\end{array}$ & $\%$ Motility \\
\hline Control & $10 \mathrm{ml} / \mathrm{kg}$ & $51.88 \pm 5.23$ & $18.77 \pm 5.35$ & 63.68 \\
\hline Castor oil & $10 \mathrm{ml} / \mathrm{kg}$ & $50.25 \pm 7.27$ & $23.5 \pm 3.31$ & 53.24 \\
\hline Chloroform extract & $200 \mathrm{mg} / \mathrm{kg}$ & $50.75 \pm 2.98$ & $32.5 \pm 4.50$ & 35.03 \\
\cline { 2 - 5 } & $400 \mathrm{mg} / \mathrm{kg}$ & $53.5 \pm 9.03$ & $36.5 \pm 6.02$ & 31.78 \\
\hline \multicolumn{4}{|l|}{ Values are represented as mean \pm SD } \\
\hline
\end{tabular}

Table 3: GIT motility activity of chloroform extract of fruits of $P$. fascicularis. chloroform extract at a dose of $400 \mathrm{mg} / \mathrm{kg}$. The motility rate of castor oil and chloroform extract are 53.24 and $31.78 \%$ respectively.

\section{Discussion}

Findings of the present study represented that the chloroform extract of $P$. fascicularis L. has considered the level of antipyretic, analgesic, anti-inflammatory, GIT motility and cytotoxic effects with a marked safety profile. When Brewer's yeast injected subcutaneously pyrexia precipitated by way of inducing the synthesis of prostaglandin consequently a useful mechanism for the screening of plants substances as well as artificial drugs for their antipyretic effect [23]. Thus, depletion of prostaglandin synthesis might be the viable mechanism of antipyretic motion as that paracetamol do by means of blocking the cyclooxygenase enzyme pastime [24]. The intraperitoneal administration of chloroform extract of $P$. fascicularis L. Extensively reduced rectal temperature of yeast prompted febrile mice. Thus it may be assumed that chloroform extract of $P$. fascicularis $L$. Contained pharmacologically active compounds that intrude with the release of prostaglandins [25] and the antipyretic action of the n-hexane fraction of Viola odorata [26] complement the antipyretic activity of our examined extract. Acetic acid-caused writhing is a well advocated protocol in evaluating medicinal agents for their analgesic property. Some endogenous ache mediators such as arachidonic acid through cyclooxygenase, and

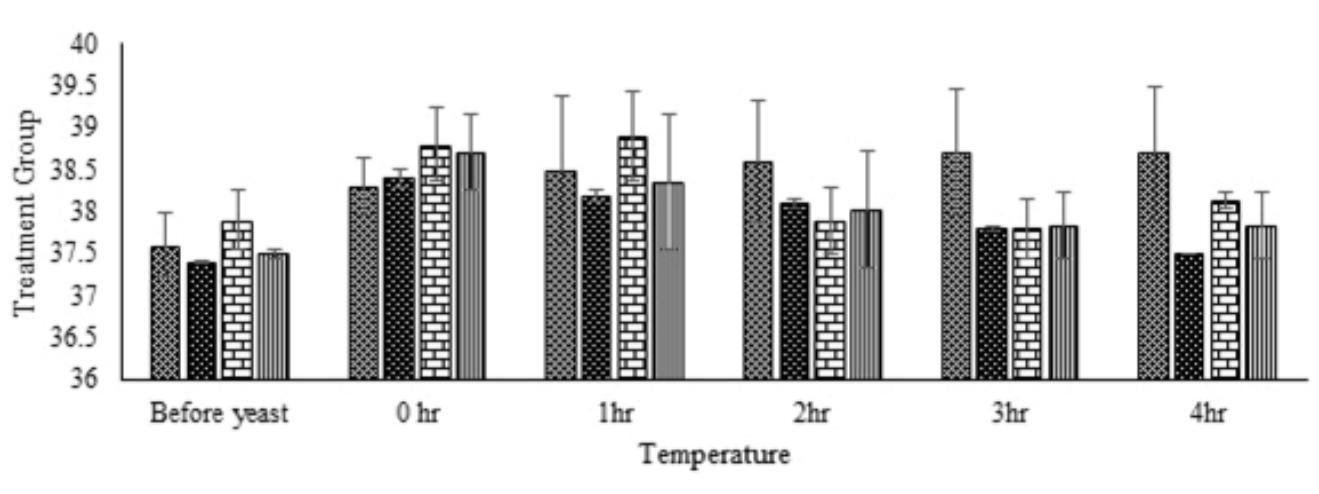

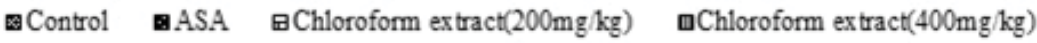

Figure 1: Effect of the chloroform extract (fruit) of $P$ fascicularis on yeast induced pyrexia in rat.

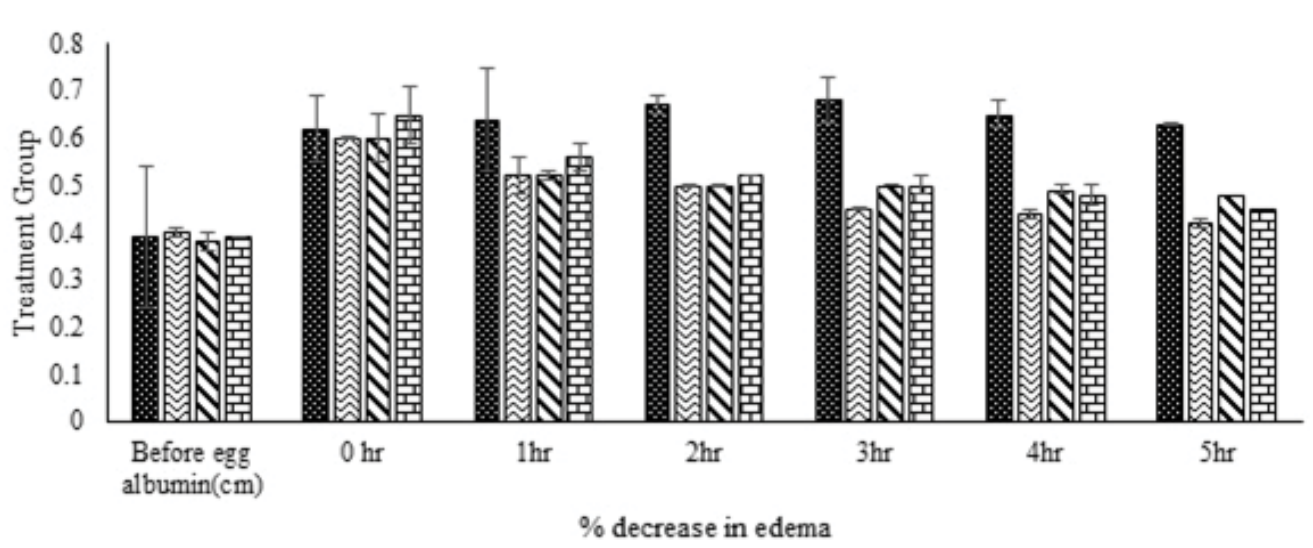

هControl $\quad$ Aspirin $\quad \Delta$ Chloroform extract $(200 \mathrm{mg} / \mathrm{kg}) \quad \nabla C h l o r$ form extract $(400 \mathrm{mg} / \mathrm{kg})$

Figure 2: Effect of chloroform extract of $P$.fascicularis (fruit) on egg-albumin induced edema in mice. 
prostaglandin biosynthesis cause induction of pain [27]. This pain paradigm is extensively used for the assessment of peripheral analgesic interest because of its sensitivity and response to the compounds at a dose which is not effective in other techniques. The likely reason of stomach writhing's neighborhood peritoneal receptor [27]. In acetic acid prompted writhing paradigm pain sensation is determined via producing localized inflammatory response because of generating prostaglandin in particular PGE2 and PGF2 $\alpha$ with increasing the extent of lipoxygenase products may additionally in peritoneal fluids [27]. These lipoxygenase and prostaglandin products purpose irritation and ache with the aid of increasing capillary permeability. Thus substance with analgesic impact reasons inhibition of writhing's preferably by means of inhibition of prostaglandin synthesis [28]. Regarding the consequences of our extract in acetic acid-induced belly constriction assay, a prominent inhibition of writhing reflux turned into found. These findings strongly propose that chloroform extract of $P$. fascicularis L. has peripheral analgesic activity and their mechanisms of movement can be mediated through inhibition of neighborhood peritoneal receptors. The profound analgesic pastime of chloroform extract of $P$. fascicularis L. may be because of the interference of their active principle(s) with the discharge of ache mediators. The gift study also examined the anti-inflammatory activity of the chloroform extract of $P$. fascicularis L. The plant extract showed good anti-inflammatory activity through suppressing the egg albumin induced rat paw edema both at the early and later phases of edema. The results obtained were comparable to that obtained for standard aspirin. Several inflammatory mediators including histamine, serotonin and bradykinin site of a Local inflammatory insult leading to edema through growing vascular permeability and blood drift [28]. Egg albumin precipitated edema formation inside the rat paw is a biphasic occasion. In the primary phase in all likelihood release of histamine and serotonin brought on immediately edema after the management of the irritant and lasting up to $2 \mathrm{~h}$, while at later section, edema shaped after $3 \mathrm{~h}$ to 5 h. of administration of the irritant may be because of the discharge of bradykinin, protease, prostaglandins and lysosome [29]. Edema produced into the rat paw after subcutaneous injection of egg albumin that is as a result of plasma extravasation, while increasing tissue water and plasma protein exudation together with neutrophil extravasation [30]. In the first phase reduction of edemogenesis evinced by both the garden egg extract and the garden egg incorporated diet in this study replicated that the plant is very effective in reducing the release or action of the early phase mediators. Suppression of edema within the second phase of inflammation shows that the anti-inflammatory interest of chloroform extracts of $P$. fascicularis L. May also be because of the suppression of egg albumin precipitated prostaglandins and kinnin formation inside this era. Thus continuous intake of the plant could confer protection against inflammatory edema and thus could be useful in the treatment and management of inflammatory conditions. Report by Mutalik et al. [31] support our present finding very amorously. Several studies have established the medicinal use of plants extract by investigating the biological activity of extracts of plants extract with antispasmodic effects which delay intestinal transit, stimulate water adsorption, suppress gut motility, and reduce the intraluminal fluid accumulation [32]. The present study was also accused to validate antidiarrhoea 1 efficacy chloroform extract of $P$. fascicularis $L$. in the experimental models of mice with diarrhoea. In the contemporary examine the chloroform extract of $P$. fascicularis L. have resembled antidiarrhoea 1 potential in experimental animal models. Despite the heterogeneity of etiologies of diarrhoea, previous study data state four major patho-physiologies may responsible for clinical development of diarrhoea. These include expanded electrolytes secretion (secretory diarrhoea), extended luminal osmolality (osmotic diarrhoea), decreased electrolytes absorption, and a decreased transit time through deranged intestinal motility [33]. Most of the antidiarrhoea l agents found out antidiarrhoea 1 consequences by way of decreasing the gastrointestinal motility and/or the secretions [34], while diarrhoea causing agents like laxatives promote this two distinct of pathological development of diarrhoea . During laboratory study castor oil used as an inducer of diarrhoea; because of its well established laxative effects. Castor oil is set off diarrhoea through modifying electrolyte permeability of the intestinal membrane and through extended prostaglandin biosynthesis and release $[35,36]$. Different researches have shown that castor oil induce diarrhoea within 1-2 h just after administration of $0.1 \mathrm{ml}$ to $0.3 \mathrm{ml}$ on experimental animal model [37]. In our present study diarrhoea was occurred within $1 \mathrm{~h}$ because of the high dose of castor oil $(0.5 \mathrm{ml} / \mathrm{mice})$. Mice's that showed the diarrhoea 1 response were only subjected for the evaluation of anti-diarrhoea 1 activity of chloroform extract of $P$. fascicularis L. The plant extract demonstrated significant reductions of frequency of defecation, water contents, and intestinal fluid accumulation. On the other hand, findings from gastrointestinal motility test indicated its poor anti motility effect. The overall findings show that experimental plant extract demonstrated a considerable antidiarrhoea $l$ activity.

\section{Conclusion}

In conclusion, the chloroform extract of $P$. fascicularis $\mathrm{L}$ turned into proved an herbal safe remedy for the remedy of pyrexia, analgesia, diarrhoea and irritation. Our current findings supported clinical rationale for the folk's use of the plant as antidiarrhoea l, antipyretic, analgesic and anti-inflammatory agent. Nevertheless, present observe also needs the isolation of natural secondary metabolites from the plant will assist us in addition in narrating the biological pathways of those agents and identification of most important accountable compounds of medical application.

\section{Acknowledgment}

The authors are thankful to the Department of Pharmacy, Noakhali Science and Technology University for giving the allowance to take laboratory facilities throughout the study.

\section{Ethical Statement}

All study animals received human care according to the criteria outlined in the 'Guide for the Care and Use of Laboratory Animals', $8^{\text {th }}$ edition, prepared by the National Academy of Sciences and published by the National Institute of Health.

\section{References}

1. Qayum RA, Khan MD, Moghal MMR, Amin MN, Hossain MS, et al. (2013) Analgesic and antipyretic activities of two medicinal plants-Salvinia minima and Dactyloctenium australe in experimental animal models. Der Pharmacia Sinica 4: 183-187.

2. Majumder MS, Amin MN, Moghal MMR, Banik S, Kar A, et al. (2014) Anthelmintic and cytotoxic activities of two medicinal plants: Polygonum viscosum and Aphanamixis polystachya Growing in Bangladesh. J Sci Res 6: 339-345.

3. Barrett B, Kiefer D, Rabago D (1999). Assessing the risks and benefits of herbal medicine: An overview of scientific evidence. Altern Ther Health Med 5: 40-49.

4. Duke JA (1990) Promising phytomedicinals. In: Janick J, Simon JE (eds.) Advances in new crops. Timber Press, Portland, pp: 491-498.

5. Matu EN, Staden JV (2003) Antibacterial and anti-inflammatory activities of some plants used for medicinal purposes in Kenya. J Ethno pharmacol 87: $35-41$.

6. Ellof JN (1998) Which extractant should be used for the screening and isolation of antimicrobial components from plants. J Ethnopharmacol 60: 1-6.

7. Lechat IV, Menut C, Roig B, Bessiere JM, Lamaty G (1996) Isoprene related 
Citation: Baul S, Amin MN, Hussain MS, MEH Mukul, Millat MS, et al. (2017) Phytochemical Nature and Pharmacological Evaluation of Chloroform Extract of Pandanus fascicularis L. (Fruits): An in vivo Study. J Bioanal Biomed 9: 223-228. doi:10.4172/1948-593X.1000183

esters, significant components of Pandanu stectorius. Phytochemistry 43 1277-1279

8. Loeser JD, Treede RD (2008) The Kyoto protocol of IASP basic pain terminology. Pain 137: 473-477

9. Dewan SMR, Amin MN, Adnan T, Uddin SMN, Shahid-Ud-Daula AFM, et al. (2013) Investigation of analgesic potential and in vitro antioxidant activity of two plants of Asteraceae family growing in Bangladesh. J Pharm Res 6: 599-603.

10. Rajani GP, Deepak Gupta, Sowjanya K, Sahithi B (2011) Screening of antipyretic activity of aerial parts of Nelumbonuci feragaertn in yeast induced pyrexia. Pharmacologyonline 1: 1120-1124

11. Duraisankar M, Ravichandran V (2012) Antipyretic potential of polyherbal ayurvedic Products. Asian J Pharma Clin Res 5: 146-150.

12. Gomathi P, Mazumder UK, Gupta M (2011) Antipyretic potential of Galega pupurea root. Intl Res J Phar 2: 151-152.

13. Anosike CA, Obidoa O, Ezeanyika LU (2012) Membrane stabilization as a mechanism of the anti-inflammatory activity of methanol extract of garden egg (Solanum aethiopicum). DARU J Pharm Sci 6: 20:76.

14. Hossain H, Shahid-Ud-Daula AFM, Hasan K, Mansur AA, Haq MM (2012) Antiinflammatory activity, total flavonoids and tannins content from the ethanolic extract of Spilanthes paniculata leaf growing in Bangladesh. Int J Pharm 2 271-277.

15. Halliwell B, Gutteridge JMC, Cross CE (1992) Free radicals, antioxidants, and human disease: Where are we now? J Lab Clin Med 119: 598-620.

16. Hussain MS, Hossain MS, Sen N, Rahman MA, Halim M (2017) Elucidation of membrane stabilizing potentials of methanolic extract of Vigna unguiculata (cowpea) Linn. (seed). Discovery Phytomedicine 4: 8-12.

17. Sarker MAA, Banik S, Hussain MS, Ghosh A, Hossain MS (2016) In-Vitro and in-vivo pharmacological activities with phytochemical evaluation of methanolic Extract of Microcos paniculata stem barks. Current Drug Therapy 11: 142-149.

18. Shoba FG, Thomas M (2014) Evaluation of anti-diarrhoeal effect of four medicinal plants on castor oil induced gastrointestinal motility in mice. Advances in Applied Science Research 5: 153-156.

19. Atata RF, Sani A, Ajewole SM (2003) Effect of stem bark extracts of Enantia chloranta on some clinical isolates. Niger Soc Exp Biol 15: 84-92.

20. Amin MN, Banik S, Ibrahim M, Moghal MMR, Majumdar MS, et al. (2015)AStudy on Ardisia solanacea for evaluation of phytochemical and pharmacological properties. Inter J Pharmacog Phyto Res 7: 8-15.

21. Guenka LC, Gomes RC, Melo VL, Kitanishi CRR, Pereira PS, et al. (2008) Antiinflammatory and anti-nociceptive effects of Zeyheria montana (Bignoniaceae) ethanol extract. Memórias do Instituto Oswaldo Cruz 103: 768-772.

22. Rahman MK, Chowdhury MAU, Islam MT, Chowdhury MA, Uddin ME, et al.
(2015) Evaluation of antidiarrheal activity of methanolic extract of Maranta arundinacea Linn. leaves. Advan Pharmacol Sci 257057: 6

23. Devi BP, Boominathan R, Mandal SC (2003) Evaluation of antipyretic potentia of Cleome viscosa Linn. (Capparidaceae) extract in rats. J Ethnopharmaco 87: $11-13$

24. Moltz H (1993) Fever: Causes and consequences. Neurosci Biobehav Rev 17 237-269.

25. Rawlins M, Karger AG (1973) Mechanism of salicylate-induced antipyresis Biomed central, p: 311

26. Toiu A, Vlase L, Oniga I, Tamas M (2008) Quantitative analysis of some phenolic compounds from viola species tinctures. Farma J 56: 440-445.

27. Khattak SG, Gilani SN, Ikram M (1985) Antipyretic studies on some indigenous Pakistani medicinal plants. J Ethnopharmacol 14: 45-51.

28. Duarte I, Nakamura M, Ferreira S (1988) Participation of the sympathetic system in acetic acid-induced writhing in mice. Braz J Med and Bio Res 21: 341.

29. Kang HS, Lee JY, Kim CJ (2008) Anti-inflammatory activity of arctigenin from Forsythiae fructus. J Ethnopharmacol 116: 305-310.

30. Wallace JM (2002) Nutritional and botanical modulation of the inflammatory cascade: Eicosanoids, cyclooxygenase and lipoxygenase-as an adjunct in cancer therapy. Integr Cancer Ther 1: 7-37.

31. Yankanchi SR, Koli SA (2010) Anti-inflammatory and analgesic activity of mature leaves of methanol extract of Clerodendrum inerme L (Gaertn). J Pharm Sci Res 11: 782-785

32. Mutalik S, Paridhavi K, Mallikarjuna C, Udupa N (2003) Antipyretic and analgesic effect of leaves of Solanum melongena in rodents. Indian J Pharmacol 35: 312-315.

33. Gutiérrez SP, Mendoz DZ, Munive AH, Martínez AM, González CP (2013) Antidiarrheal activity of 19-deoxyicetexone isolated from Salvia ballotiflora Benth in mice and rats. Molecules 18: 8895-8905.

34. Abate G (1989) Etse Debdabe: Ethiopian Traditional Medicine. Addis Ababa: Addis Ababa University press.

35. Agbor GA, Léopold T, Jeanne N (2004) The antidiarrhoeal activity of Alchornea cordifolia leaf extract. Phytother Res 18: 873-876.

36. Besra SE, Gomes A, Chaudhury L, Vedasiromoni JR, Ganguly DK (2002) Antidiarrheal activity of seed extract of Albizzi alebbek Benth. Phytother 16 529-533.

37. Brijesh S, Daswani P, Tetali P, Antia N, Birdi T (2009) Studies on the antidiarrhoeal activity of Aegle marmelos unripe fruit: Validating its traditional usage. BMC Complement Altern Med 9:1-12. 